\title{
COLOR DOPPLER SONOGRAPHY WITH CONTRAST IN THE DIFFERENTIATION OF OVARIAN TUMORS
}

\author{
Eduardo Cardoso Blanco, Ayrton Roberto Pastore, Angela Maggio da Fonseca,
} Filomena Marino Carvalho, Jesus Paula Carvalho and José Aristodemo Pinotti

BLANCO EC et al. - Color Doppler sonography with contrast in the differentiation of ovarian tumors. Rev. Hosp. Clín. Fac. Med. S. Paulo 58(4):185-192, 2003.

The objective of this study was to differentiate benign ovarian tumors from malignant ones before surgery using color and pulsed Doppler sonography, and to compare results obtained before and after use of contrast medium, thereby verifying whether contrast results in an improvement in the diagnostic sensitivity.

METHODS: Sixty two women (mean age 49.9 years) with ovarian tumors were studied, 45 with benign and 17 with malignant tumors. All women underwent a transvaginal color Doppler ultrasonographic exam. A study of the arterial vascular flow was made in all tumor areas, as well as an impedance evaluation of arterial vascular flow using the resistance index.

RESULT: Localization of the vessels in the tumor revealed a greater proportion of malignant tumors with detectable internal vascular flows (64\%) than benign tumors with such flows $(22 \%)$. There was a considerable overlap of these findings. The use of contrast identified a greater number of vessels with confirmation in the totality of tumors, but did not improve the Doppler capacity in tumoral differentiation. Malignant tumors presented lower values of resistance index than the benign ones, whether or not contrast was used. The cutoff value for resistance index that better maximized the Doppler sensitivity and specificity was 0.55 . Through this value, an increase of the sensitivity after contrast use was obtained, varying from $47 \%$ to $82 \%$, while specificity remained statistically unchanged.

CONCLUSION: Although the injection of a microbubble agent improved the sensitivity of the method detecting vascularization of tumors, a positive finding for vascularization by this method was not clinically useful in the differentiation of benign and malignant ovarian tumors. medium.

DESCRIPTORS: Transvaginal ultrasound. Color Doppler sonography. Adnexal mass. Ovarian neoplasms. Contrast

Considerable evidence indicates that neovascularization is responsible for the tumoral growth and invasion ${ }^{1}$. Ultrasonography with color and pulsed Doppler provides dynamic information concerning the distribution of tumor vessels and their impedance value through the determination of resistance (RI) and pulsatility (PI) indices. Preliminary data suggests that it is possible to detect vascular changes associated with angiogenesis in early ovarian cancer through this technique $^{2}$. A possible explanation for these changes is that the new blood vessels present in the carcinomas have limited muscular tonus due to the absence of the medial layer and that together with numerous existing arterio-

From the Division of Gynecologic Oncology of the Departments of Gynecology and Obstetrics, and the Department of Radiology, Hospital das Clínicas, Faculty of Medicine, University of São Paulo - São Paulo/SP, Brazil.

Received for publication on July 03, 2002. venous shunts, they would be responsible for the low impedance registered by the RI and PI indices. However, this method presents some restrictions associated with the inaccessibility to the small caliber vessels, thus demonstrating low sensitivity for the intended purpose $^{3}$. The advent of echo-enhancing substances for endovenous use, according to experiences in other organs $^{4}$, would allow better visibility of these vessels, thereby helping in the differentiation of the neoplastic process. 
The objective of this study was to differentiate benign from malignant tumors prior to surgery by using color and pulsed Doppler and to compare the results before and after use of contrast so that any improvements in resulting diagnostic sensitivity and specificity could be verified.

\section{MATERIAL AND METHODS}

This study comprised 62 women with ages varying from 13 to 84 years (average 49.9 years) with histologically confirmed ovarian tumors, 45 benign and 17 malignant ones. All patients underwent surgery, and the classification of histologic findings was made according to the World Health Organization criteria. The patients signed a consent form, as approved by the Research Ethics Committee of our University.

\section{Contrast medium}

All patients received the ultrasound contrast agent Levovist ${ }^{\circledR} 400$ $\mathrm{mg} / \mathrm{mL}(8 \mathrm{~mL}$ ) intravenously via peripheral vein. Levovist ${ }^{\circledR}$ (Schering AG, Berlin FRG) is a suspension of especially manufactured galactose containing $99.9 \%$ galactose microparticles and a very low concentration of palmitic acid. Each vial contained $4 \mathrm{~g}$ of microparticles, and after suspension in water for injection was administered as a bolus via an 18-gauge plastic cannula inserted into the arm vein (injection speed: $1-2 \mathrm{~mL} / \mathrm{second}$ continuously). This was followed by an additional $10 \mathrm{~mL}$ of physiological saline solution to flush the cannula using the same injection rate. A comparison was made of the Doppler sonographic findings before and after injection of Levovist ${ }^{\circledR}$. Although repetitive injections of the product were permitted (up to the maximum of 6 units) none of the cases required an additional injection.

\section{Equipment and analysis of color Doppler signals}

The ultrasonographic transvaginal exam with Doppler was performed with a commercially available scanner, GE LOGIC $^{\mathrm{TM}} 500$, version 2.0, with abdominal and transvaginal transducers of $3.5 \mathrm{MHz}$ and $5.0 \mathrm{MHz}$ respectively. A Doppler filter of $50 \mathrm{~Hz}$ was used to eliminate low-frequency signals resulting from vessel wall motion. The color Doppler gain was increased until noise appeared and then was reduced until the noise was totally suppressed (usually this was a $50 \%$ reduction). Whenever the tumors exceeded $10 \mathrm{~cm}$ diameter, the study was completed via transabdominal ultrasonography. In premenopausal patients, the examination was performed between the $3^{\text {rd }}$ and $10^{\text {th }}$ days of the menstrual cycle in order to avoid the effects on the ovarian vascularization provoked by ovulation and the luteal body. The settings of the scanner controls were not altered after the injection of contrast. Vascular arterial flows were studied in all tumor areas, as was the impedance of vascular flows using RI determination. The vessels were classified as internal or peripheral according to their location. When the flow was measured in more than one vessel, the vessel with the lowest RI was chosen for study.

The video output of the scanner was tape recorded starting at 5 seconds prior to injection and continuing until the intensity of the color Doppler signals was subjectively judged to return to the base-line level. The number of vessels was evaluated within $10 \mathrm{~mm}$ of the tumors in the peripheral and central location.

The same examiner performed all ultrasonographic examinations.

The chi-square test was used to statistically evaluate the quantitative variables. A canonical correlation was applied to the sets of variables ob- served in both methods (with and without contrast) aiming at evaluating their relationship. The classification power regarding malignancy of the method used, with or without contrast, was analyzed with focus on the specificity and sensitivity of measurements that were based on Youden's index and the receiver operating characteristics (ROC). A $p$ value below 0.05 was considered to be a statistically significant difference.

\section{RESULTS}

When determining the RI by Doppler technique without the use of contrast, it was possible to reproduce arterial flow in only 45 cases, which were therefore used for the comparative analysis between the 2 examination modalities, without and with contrast (Table 1).

After injection of the contrast during the color Doppler exam, enhancement of vascular signals presented by the adnexal masses was found at a mean time of 25 seconds \pm 14 (SD), this effect remaining for a variable period of time of 185 seconds \pm 45 (SD). All patients presented an increase of Doppler sign intensity, with the appearance of new vessels in $77 \%$ of the tumors (Figs. 1, 2).

Regarding the RI, the measures of central tendency (mean) and of variability (standard deviation) observed in the benign and malignant tumor groups are presented in table 2 .

Statistically significant differences $(p<0.001)$ were observed between the average values for both RI1 and RI2 in the benign vs. malignant comparisons. The average values of RI1 and RI2 were not significantly different in either the benign or the malignant tumor group comparisons (Table 2).

Regarding vessel location in tumors, a higher proportion of malignant tumors had internal vascular flows 
Table 1 - Histologic diagnosis and results of blood flow distribution in 62 ovarian tumors without use of contrast.

\begin{tabular}{lcccc}
\hline Pathologic Diagnosis & Number & \multicolumn{2}{c}{ Vessels } & \\
& & Absent & Peripheral & Central \\
\hline Benign & 11 & 12 & 2 & \\
$\quad$ Cystadenoma 25 & 3 & & 3 & \\
$\quad$ Endometrioma & 9 & 3 & 2 & 4 \\
$\quad$ Dermoid cyst & 1 & & & 1 \\
Thecoma & 1 & 1 & 2 & 1 \\
Fibroma & 4 & & 1 & 1 \\
Cystadenofibroma & 2 & & & \\
Others & & & 1 & \\
& 10 & 2 & 2 & \\
Malignant & 5 & & 1 & \\
$\quad$ Cystadenocarcinoma & 1 & & & \\
Borderline & 1 & & & \\
$\quad$ Clear cell carcinoma & & & & \\
$\quad$ Granulosa cell tumors & 1 & & & \\
\hline
\end{tabular}

within a solid component or septation (64\%) than did benign tumors with internal flows $(22 \%)$. A significantly greater number $(\mathrm{c} 2=10.06, p=0.0065)$ of benign compared to malignant tumors had peripheral flow without evidence of internal flow (Table 1). The use of contrast allowed the identification of a greater number of centrally located vessels in both groups of tumors, with this increase being more evident in benign tumors, in contrast with the results obtained without the use of contrast (Fig. 2)

Whether or not contrast was used, the malignant tumors had smaller RI values than the benign ones did (Table 2).

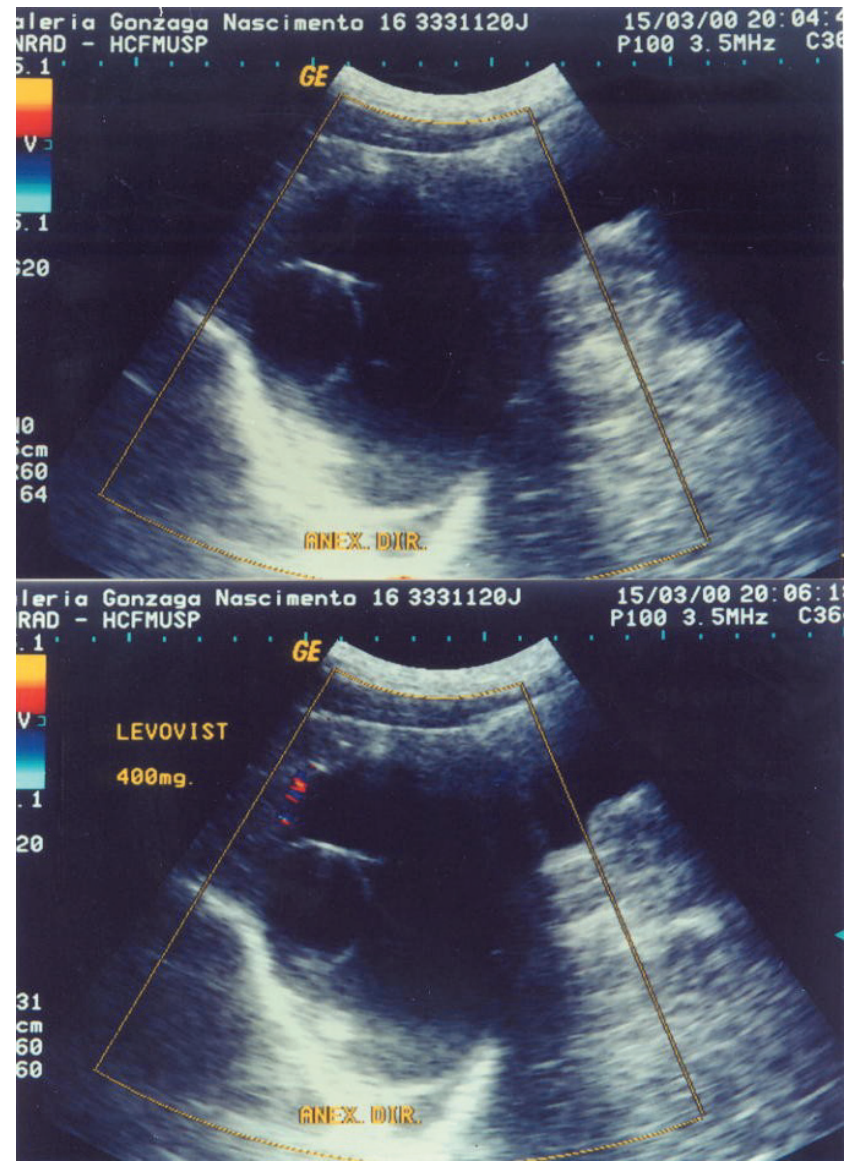

Figure 1 - Serous cystadenoma of the ovary. (a) Cystic formation of anechoic contents with presence of heterogeneous septa and lack of blood vessels at transvaginal color Doppler ultrasonography. (b) After administration of echographic contrast, very few vessels of peripheral location were identified.

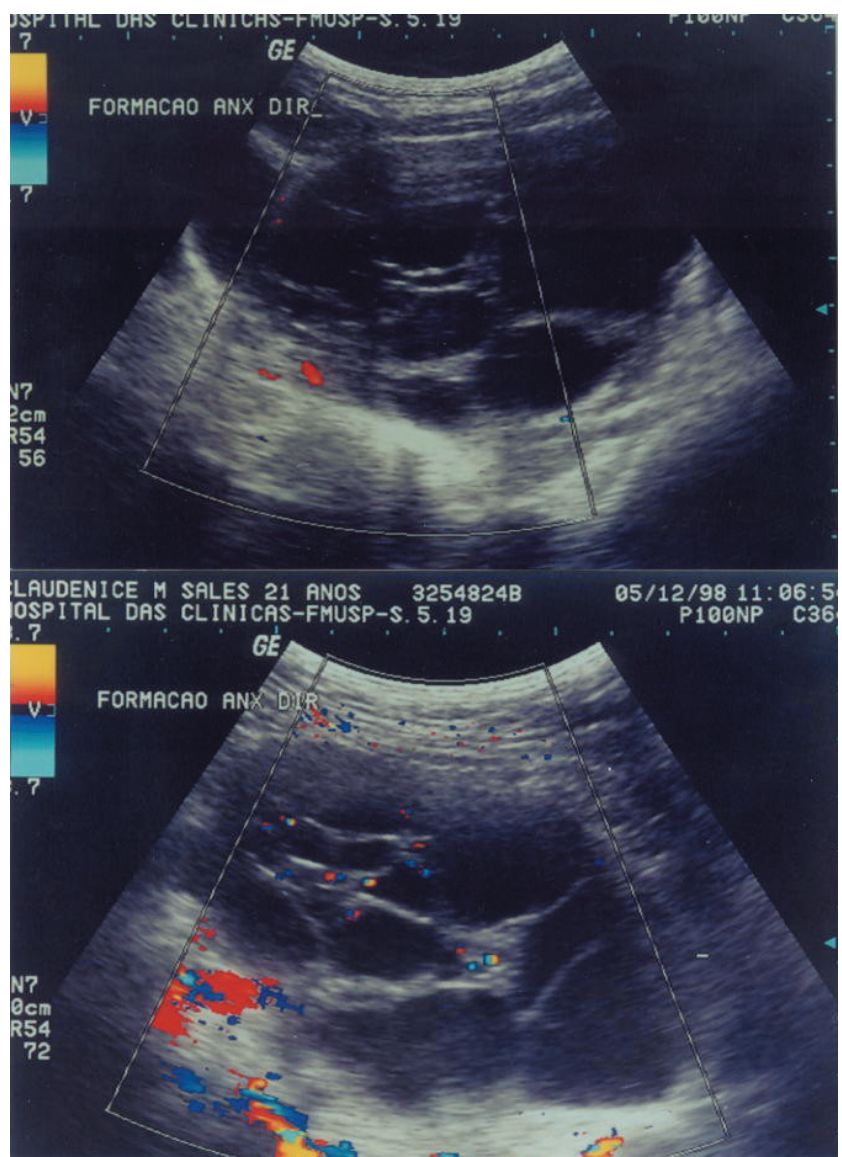

Figure 2 - Mucinous cystadenoma of the ovary. (a) Cystic formation of irregular walls, predominant anechoic of contents with discreet echogenic points (debris) in its interior; presence of numerous heterogeneous and confluent septations. Color Doppler shows rare blood vessels of peripheral location. (b) After use of contrast, an increase of the vascular signal with the appearance of multiple vessels in the interior septa and in the tumor periphery was noted. 
The cutoff RI value that better maximized the Doppler sensitivity and specificity was 0.55 , as demonstrated by the use of receiver operating characteristics (ROC) methodology.

It was noted that the Youden's index for all cutoff RI values was higher when the contrast was used. The comparison of sensitivity values for both methods, when considering the 0.55 cutoff value, showed a significant difference at the $8 \%$ level (the chi-square test was applied with the Yates' correction factor), thereby confirming the superior Doppler results when using contrast, based on the Rl determination (Table 3).

When the internal flow was used as an indicator of malignancy, the sensitivity and specificity for internal flow versus either peripheral or no flow through color Doppler were $65 \%$ and $78 \%$, respectively. After use of the contrast, the sensitivity and specificity were $88 \%$ and $47 \%$ respectively (Table 4).

As it can be seen, the sensitivity and specificity values of the color Doppler are low, independent of the use or not of the contrast for the classification of the tumors. There is no evidence that the increase of sensitivity observed with the use of contrast is significant $\left(\chi^{2}=1.47, p=0.2252\right.$, with Yates' correction).

\section{DISCUSSION}

The analysis of the epidemiological aspects of ovarian cancer has generated a great deal of interest, especially regarding the detection and characterization of the ovarian masses through radiological imaging. Since 1958, when for the first time Donald identified a voluminous pelvic-abdominal ovarian cyst ultrasonogra-

Table 2 - Averages and confidence intervals for RI values obtained as a result of using the Doppler technique without contrast (RI1) and with contrast (RI2)

\begin{tabular}{lllll}
\hline Method & $p$ & Diagnosis & Average & Range \\
\hline RI1 & $<0.001$ & Malignant & 0.565 & $0.38-0.81$ \\
& & Benign & 0.773 & $0.42-1$ \\
RI2 & $<0.001$ & Malignant & 0.461 & $0.33-0.57$ \\
& & Benign & 0.712 & $0.31-0.89$ \\
\hline
\end{tabular}

Note: The $p$ value (descriptive level) is related to the Fisher's exact test for comparison of averages.

Table 3 - Sensibility, specificity, predictive positive (PPV), and negative (PNV) values of Doppler without and with contrast for $\mathrm{RI}=0.55$

\begin{tabular}{lccccc}
\hline RI & Sensibility & Specificity & PPV & PNV & Youden \\
\hline Without contrast & 47 & 93 & 78 & 78 & 40 \\
With contrast & 82 & 89 & 80 & 93 & 71 \\
\hline
\end{tabular}

Note: Values are shown as percentages.

Table 4 - Specificity, sensibility and predictive positive (PPV), and negative (PNV) values of the classification based on vessel localization by the Doppler technique without and with contrast

\begin{tabular}{lccccc}
\hline Color Doppler & Sensibility & Specificity & PPV & PNV & Youden \\
\hline Without contrast & 65 & 78 & 52 & 85 & 42 \\
With contrast & 88 & 47 & 38 & 91 & 35 \\
\hline
\end{tabular}

Note: Values are shown as percentages. phically, this technique has been systematically used in differentiating between benign and malignant tumors ${ }^{5}$.

Although the transvaginal route is presently considered to produce results that are sensitive for the detection of malignancy, the diagnostic confidence is not sufficient to obviate invasive procedures like laparoscopy and laparotomy. Thus, notwithstanding the efforts for improving the diagnostic accuracy, many studies have demonstrated that morphological evaluation of transvaginal ultrasound has found $80 \%$ to $90 \%$ sensitivity and from $65 \%$ to $95 \%$ specificity ${ }^{6-8}$.

Color and pulsed Doppler have been widely investigated and proposed as possible means to augment ultrasonography in differentiating adnexal masses. Unfortunately, there is much controversy in the literature regarding the actual utility of the Doppler techniques for this application.

The presence and localization of the blood flow demonstrated through ultrasonography with color Doppler were initially used in an attempt to characterize ovarian masses ${ }^{9-12}$. Fleischer et al. ${ }^{10}$ found statistically significant differences in the location of blood vessels in benign lesions, where they tend to be peripheral, compared to malignant lesions where they tend to be central. Our data also showed a significantly higher percentage of malignant compared with benign tumors with internal flow. Similarly, the presence of a peripheral location of vessels or their absence is better related to benignity ( $\mathrm{PNV}=85 \%$ ). It is interesting to point out that $88 \%$ of the tumors in our study in which no blood flow was observed were benign $(n=15)$. Previous studies using Doppler technology also reported the rarity of identifying flows in predominantly benign ovarian masses ${ }^{12-15}$.

As a result of this and other works, it can be concluded that a significant number of tumors, either of benign or 
malignant nature, do not present blood vessels at ultrasonographic evaluation with Doppler technology. The improper concept of "lack of blood flow" in benign tumors presented by some authors ${ }^{8,16-18}$ could be resulting from technical limitations associated with Doppler ultrasound rather than from phenomena actually related to angiogenesis. Thus, care must be taken when considering whether the absence of vascularization is to be used as a criterion of assessment, since information revealed through Doppler ultrasonography is highly dependent on variations in technology and could easily change as technology improves.

Currently, the use of some new technological resources has been fundamental for the increase in the detection of blood vessels, and consequently for the diagnostic accuracy of Doppler use in the differentiation of pelvic masses. The first resources that were of technological origin did not always have satisfactory results with the use of amplitude Doppler (Angio®, Power®, Energy®, Power-Angio, etc.). Subsequently, based on experiences with other organs ${ }^{19-26}$, results have been obtained by applying echo-enhancer agents via intravenous administration. In this connection, the use of Levovistò permitted the identification of new blood vessels in tumors that had undetectable vascular flow initially and in other tumors that already had revealed vascular flow of peripheral distribution. In 12 cases of the latter, the new localization (central) was chosen for diagnostic purposes. Although more vessels were detected, the use of contrast did not improve the method's capacity for predicting malignancy. Whether or not contrast is used, color Doppler showed a limited utility in the differentiation of ovarian tumors.
When determining RI, significantly lower values were registered in malignant tumors as compared with the benign ones, independent of the use or not of contrast (Table 2). Considerable overlap of RI values was observed between the 2 groups of tumors, thus confirming the findings in other publications ${ }^{27-33}$. The lower RI values found in both groups of tumors after use of contrast would result from the detection of vascular signs of low amplitude and obviously lower resistance that were not detected by the conventional Doppler technique.

In contrast with the first studies performed with pulsed Doppler in ovarian tumors ${ }^{16,34}$, where high sensitivity $(96 \%)$ and specificity $(95 \%)$ in the identification of malignant tumors were obtained with RI $<0.40$ values, later works questioned the veracity of these findings. Thus, authors such as TEKAY \& JoupILLA ${ }^{14}$ obtained, for a RI cutoff value of $0.50,46 \%$ sensitivity and false positive rates of $11 \%$ in the detection of malignancy. The results of SCHNEIDER et al. ${ }^{35}$, for RI $<0.40$ values were remarkably similar. Subsequent studies have also showed low rates of detection for ovarian cancer when using different cutoff values ${ }^{36-39}$. The false positive rates in these investigations varied from $2 \%$ to $48 \%$.

In the population covered by this study, the discriminatory power range of RI in the differentiation of tumors was between the 0.50 and 0.60 values, from which 0.55 was the one that best maximized the sensitivity and specificity simultaneously. For this cutoff value, the pulsed Doppler without and with contrast showed specificity rates statistically similar to $93 \%$ and $89 \%$, respectively.

A variety of benign lesions might lead to an erroneous diagnosis, including teratomas ${ }^{34}$, endometriomas ${ }^{40}$, and thecomas ${ }^{41}$. In these studies, the presence of these types of tumors was confirmed following initial detection using pulsed Doppler.

A significant increase in sensitivity (from $47 \%$ to $82 \%$ ) was observed after administration of the contrast agent, leading to a significant difference at the level of $8 \%$ (chi-square test with Yates' correcting factor). The primary clinical usefulness of this technique is associated with reliability of the method for predicting benignity (PNV for malignity $=93 \%$ ). However, the problem still persists regarding the identification of malignity.

\section{CONCLUSION}

The use of echo-enhancing agents such as Levovist ${ }^{\circledR}$ considerably improved the performance of the Doppler ultrasonographic technique through the increase of the vascular signal, thereby permitting better identification of the blood vessels and analysis of the impedance standard of the blood flow originating from them. Although our data show that statistical statements can be made about benign and malignant tumors following the use of contrast agents, they are of little clinical use, especially in the context of evaluating an individual patient, because of the low sensitivity that is still present.

\section{ACKNOWLEDGMENTS}

This study was supported by the generous grants from the FAPESP ("Fundação de Amparo à Pesquisa do Estado de São Paulo”).

We thank Miss Mina R. Steinberg, Miss Claudia Vieira, and Miss Beatriz Stojanoff for their secretarial assistance. 
BLANCO EC e col. - Ultra-sonografia com Doppler colorido e uso de contraste na diferenciação dos tumores ovarianos. Rev. Hosp. Clín. Fac. Med. S. Paulo 58(4): 185-192, 2003.

O objetivo deste estudo foi diferenciar tumores ovarianos benignos e malignos antes da cirurgia através da ultra-sonografia com uso de Doppler colorido pulsátil e comparar os resultados obtidos antes e após o uso de contraste.

MÉTODO: Foram estudadas sessenta e duas mulheres (idade média de 49,9 anos) com tumores ovarianos, sendo 45 benigos e 17 malignos. Todas foram submetidas a ultra-sonografia transvaginal com Doppler colorido. A pesquisa de fluxo vascular foi realizado em todas as áreas tumorais, assim como a avaliação da impedância através do índice de resistência.

RESULTADOS: A localização dos vasos no tumor revelaram uma maior proporção de fluxo vascular interno detectável nos tumores malignos (64\%) do que nos tumores benignos $(22 \%)$. Houve entretanto uma considerável sobreposição destes achados. $\mathrm{O}$ uso de constrate foi capaz de identificar um grande número de vasos na totalidade dos tumores, mas não melhorou a capacidade do Doppler na diferenciação entre tumores benignos e malignos. Os tumores malignos apresentaram valores mais baixos de índice de resistência.IR do que os benignos, independentemente do uso de contraste. $\mathrm{O}$ valor de corte do índice de resistência. que maximizou a sensibilidade e a especificidade do Doppler foi de 0,55. Com este valor foi obtido um aumento na sensibilidade após o uso de contraste, variando de $47 \%$ a $82 \%$, enquanto a especificidade se manteve equivalente.

CONCLUSÃO: Embora a injeção de agentes produtores de microbolhas aumentem a sensibilidade do método na diferenciação da natureza do tumor, este valor não se mostrou clinicamente util na avaliação de tumores ovarianos.

DESCRITORES: Ultra-sonografia transvaginal. Doppler sonografia. Massas anexiais. Neoplasia ovariana. Meios de contraste.

\section{REFERENCES}

1. FOLKMAN J, WATSON KJ, INGBER D et al. - Induction of angiogenesis during transition from hyperplasia to neoplasia. Nature 1989; 339; 58-61.

2. HATA K, HATA T - Intratumoral blood flow analysis in ovarian cancer. J Ultrasound Med 1996; 15: 571-5.

3. LEVINE D- Color Doppler imaging for the detection of ovarian malignancy is unreliable (letter). Ultrasound Obstet Gynecol 1995; 6: 451-4.
4. ERNST H, HAHN EG, BALZER T et al. - Color Doppler ultrasound of liver lesions: signal enhancement after intravenous injection of the ultrasound contrast agent Levovist. J Clin Ultrasound 1996; 24: 31.

5. BONILLA-MUSOLES F - Posibilidades de diagnóstico precoz en el cáncer de ovario. In: BONILLA-MUSOLES F. Tratado de endosonografia en obstetricia y ginecologia. $2^{\text {nd }}$ ed. Barcelona, Mason-Salvat, 1992. p.269-85. 
6. BENACERRAF BR, FINKLER NJ, WOJCIECHOWSKI C et al KNAPP RC - Sonographic accuracy in the diagnosis of ovarian masses. J Reprod Med 1990; 35: 491-5.

7. SASSONE AM, TIMOR-TRITSCH IE, ARTNER A et al Transvaginal sonographic characterization of ovarian disease: evaluation of a new scoring system to predict ovarian malignancy. Obstet Gynecol 1991; 78: 70-6.

8. SENGOKU K, SAITOH T, SITOH $\mathrm{S}$ et al. - Evaluation of transvaginal color Doppler sonography, transvaginal sonography and CA 125 for prediction of ovarian malignancy. Int J Obstet Gynecol 1994; 46: 39-43.

9. KAWAI M, KANO T, KIKKAWA F et al. - Transvaginal Doppler ultrasound with color flow imaging in the diagnosis of ovarian cancer. Obstet Gynecol 1992; 79: 163-7.

10. FLEISCHER AC, RODGERS WH, KEPPLE DM et al. - Color Doppler sonography of ovarian masses: a multiparameter analysis. J Ultrasound Med 1993; 12: 41-8.

11. KURJAK A, PREDANIC M, KUPESIC-UREK $\mathrm{S}$ et al. Transvaginal color and pulsed Doppler assessment of adnexal tumor vascularity. Gynecol Oncol 1993; 50: 3-9.

12. CARTER J, LAU M, FOWLER J et al. - Blood flow characteristics of ovarian tumors: implications for ovarian cancer screening. Am J Obstet Gynecol 1995; 172: 901-7.

13. KURJAK A, SCHULMAN H, SOCIC A et al. - Transvaginal ultrasound, color flow, and Doppler waveform of the postmenopausal adnexal mass. Obstet Gynecol 1992; 80: 917 21.

14. TEKAY A, JOUPPILA P - Validity of pulsatility and resistance indices in classification of adnexal tumors with transvaginal color Doppler ultrasound. Ultrasound Obstet Gynecol 1992; 2: $338-44$.

15. TIMOR-TRITSCH IE, LERNER JP, MONTEAGUDO A et al. Transvaginal ultrasonographic characterization of ovarian masses by means of color flow-directed Doppler measurements and a morphologic scoring system. Am J Obstet Gynecol 1993; 168: 909-13

16. KURJAK A, ZALUD I, JURCOVIC D et al. - Transvaginal color Doppler for the assessment of pelvic circulation. Acta Obstet Gynecol Scand 1989; 68: 131-5.

17. KURJAK A, JURCOVIC D, ALFIVERIC Z et al. - Transvaginal color Doppler imaging. J Clin Ultrasound 1990; 18: 227-34.

18. KURJAK A, ZALUD I - Transvaginal colour flow imaging and ovarian cancer. Br Med J 1990; 300: 330-5.

19. BURNS PN, LIU JB, HILPERT P - Intravenous US contrast agent for tumor diagnosis: quantitative studies. Radiology 1990; 177: 140

20. FRITZSCH T, HAUFF P, HELDMANN F et al. - Preliminary results with a new liver specific ultrasound contrast agent. Ultrasound Med Biol 1994; 20: 137.

21. LLICETO S, CAIATI C, ARAGONA P et al. -Improved Doppler signal intensity in coronary arteries after intravenous peripheral injection of a lung-crossing contrast agent (Levovist). J Am Coll Cardiol 1994; 23: 184-190.
22. COSGROVE D, MCCREADY VR, BAMBER JC et al. - Microbubble contrast agent for color Doppler effect on breast masses. Work in progress. Radiology 1996; 198: 679-86.

23. RIES F - Clinical experience with echo-enhanced transcranial Doppler and duplex imaging. J Neuroimaging 1997; 7: 15-21.

24. BOGERS HA, SEDELAAR JP, BEERLAGE HP et al. - Contrastenhanced three-dimensional power Doppler angiography of the human prostate: correlation with biopsy outcome. Urology 1999; 54: 97-104.

25. HOSTEN N, PULS R, LEMKE AJ et al. - Contrast-enhanced power Doppler sonography: improved detection of characteristic flow patterns in focal liver lesions. Rofo Fortschr Geb Rontgenstr Neuen Bildgeb Verfahr 1999; 27: 107-15.

26. HARVEY CJ, BLOMLEY MJ, ECKERSLEY RJ et al. - Pulse-inversion mode imaging of liver specific microbubbles: improved detection of subcentimetre metastases. Lancet 2000; 355: 807-8.

27. FLEISCHER AC, RODGERS WH, RAO BK et al. - Assessment of ovarian tumor vascularity with transvaginal color Doppler sonography. J Ultrasound Med 1991; 10: 563-8.

28. HATA K, HATA T, MANABE A, SUGIMURA K et al. - A critical evaluation of transvaginal Doppler studies, transvaginal sonography, magnetic resonance imaging and CA 125 in detecting ovarian cancer. Obstet Gynecol 1992; 80: 922-6.

29. HAMPER UM, SHETH S, ABBAS FM et al. - Transvaginal color Doppler sonography of adnexal masses: differences in blood flow impedance in benign and malignant lesions. Am J Radiol 1993; 160: 1225-8.

30. PRÖMPELER HJ, MADJAR H, SAUERBREI W et al. - Quantitative flow measurements for classification of ovarian tumors by transvaginal color Doppler sonography in postmenopausal patients. Ultrasound Obstet Gynecol 1994; 4: 406-13.

31. WU CC, LEE CN, CHEN TM et al. -Incremental angiogenesis assessed by color Doppler ultrasound in the tumorigenesis of ovarian neoplasms. Cancer 1994; 73: 1251-6.

32. BROWN DL, FRATES MC, LAING FC et al. - Ovarian masses: can benign and malignant lesions be differentiated with color and pulsed Doppler US? Radiology 1994; 190: 333-6.

33. BLANCO EC - O valor da Dopplervelocimetria com mapa de cores no estudo dos tumores ovarianos [Dissertação]. São Paulo, 1996. (Faculdade de Medicina da Universidade de São Paulo).

34. BOURNE T, CAMPBELL S, STEER C et al. - Transvaginal color flow imaging: a possible new screening technique for ovarian cancer. Br Med J 1989; 299: 1367-70.

35. SCHNEIDER VL, SCHNEIDER A, REED KL et al. - Comparison of Doppler with two-dimensional sonography and CA 125 for prediction of malignancy of pelvic masses. Obstet Gynecol 1993; 81: 983-8.

36. WU CC, LEE CN, CHEN TM, LAI JI et al. - Factors contributing to the accuracy in diagnosing ovarian malignancy by color Doppler ultrasound. Obstet Gynecol 1994b; 84: 605-8.

37. BROMLEY B, GOODMAN H, BENACERRAF BR - Comparison between sonographic morphology and Doppler waveform for the diagnosis of ovarian malignancy. Obstet Gynecol 1994; 83: $434-7$. 
38. LEVINE D, FELDSTEIN V, BABCOOK C et al. - Sonography of ovarian masses: poor sensitivity of resistive index for identifying malignant lesion. Am J Roentgenol 1994; 162: 1355-9.

39. BLANCO EC, CARVALHO JP, CARVALHO FM et al. - Valor del Doppler colorido transvaginal en la diferenciación de los tumores ovarianos benignos de malignos. Rev Imag 2000; 4: 37-9.
40. KIRCHLER H, SCHWEGEL P, ENTNER C - Physiologische durchblutung des ovars: endosonographische farb Dopplerblutflussanalyse. Gynakol Geburtshilfe Rundsch 1992; 1: 90-100.

41. WILLIAMS LL, FLEISCHER AC, JONES HW - Transvaginal color Doppler sonography and CA-125 elevation in a patient with ovarian thecoma and ascites. Gynecol Oncol 1992; 46: $115-8$. 